\title{
The evolution of profile and motivations of agro-tourists in Rio Grande do Sul/Brasil
}

Elisabeth Kastenholz*

Universidade de Aveiro (Portugal)

Eurico de Oliveira Santos**

Universidade Luterana do Brasil (Brasil)

\begin{abstract}
This article aims to assess the profile of agro-tourists and their motivations for agro- and rural tourism, from the point of view of the owners of agro-tourism establishments in the Southern Half of the state Rio Grande do Sul, in Brazil. Data was collected in a census approach of the rural tourism properties in four distinct moments in time, between 1997 and 2011. Results show that most tourists are domestic, come for short breaks, even though overcoming distances of several hundreds of kilometers, with many showing loyalty to the unit. Although relaxation and escape from urban life is a main motive visible, there is an apparent trend towards more diversified tourism motivations, and activities sought, yielding relaxing, recreational, healthy, culturally enriching and emotional tourist experiences, associated to the specificities of the visited territory and rural tourism property.
\end{abstract}

Key Words: Rio Grande do Sul/ Brasil, rural tourist market, tourist motivations, agro-tourism, Market evolution.

\section{La evolución del perfil y las motivaciones de los agro-turismo en Rio Grande do Sul / Brasil}

Resumen: El presente trabajo visa conocer al perfil de los agro-turistas y a sus motivaciones para el agro-turismo y turismo rural, del punto de vista de los proprietarios de las unidades de agro-turismo en la mitad Sul del Estado de Rio Grande do Sul, en Brazil. Datos recogiran-se por un proceso de censo referente a todas las propriedades de turismo rural en quatro momentos distintos en el tiempo, entre 1997 y 2011. Los resultados muestran que los turistas son maioritariamente domesticos, hacen una visita de curta duración, mismo llegando de distancias de varias centenas de kilómetros, sendo relevante el nível de lealdad a la unidad de agro-turismo observado en gran parte del mercado. Aparte de los motivos principales de relajamiento y fuga de la vida urbana, visibles en los datos, hay una tendencia aparente en dirección a motivaciones turisticas mas diversificadas, visando experiencias relajantes, recreativas, sanas, culturalmente enriquecedores y emocionantes, associadas a las specificidades del território e de la unidad de agro-turismo visitados.

Palabras Clave: Rio Grande do Sul/ Brasil, Mercado turístico rural, motivaciones turísticas, agroturismo, la evolución del mercado.

\footnotetext{
* Phd in Tourism by the Universidade de Aveiro, MBA by ISEE/ Universidade do Porto, graduate in Tourism Management and Planning by the Universidade de Aveiro, Associate Professor at DEGEI, University of Aveiro, researcher at GOVCOPP; E-mail: elisabethk@ua.pt.

** Phd in Agroscience and Natural Resources by the Universidad Autónoma del Estado de México - UAEMEX. Agro-Engineeer by Universidade Luterana do Brasil - ULBRA. Professor Adjunto at Universidade de Caxias do Sul - UCS; E-mail: eurico58@terra.com.br.
} 


\section{Introduction}

Rural tourism has led many rural areas to the, sometimes exaggerated, hope of solving all kind of problems, being perceived as a miraculous development tool (Ribeiro \& Marques, 2002; Sharpley \& Roberts, 2004). Some stress the potential of tourism diversifying the local rural economy and thereby overcoming agricultural crisis through alternative economic activities (OCDE, 1994; Sharpley \& Roberts, 2004), inclusively helping maintain the agricultural activity, being a welcome additional source of income for farmers (Sharpley \& Vass, 2006). As a matter of fact, authors like Cavaco (1995) and Almeida \& Souza (2006) highlight the role of agricultural activity as a main ingredient and attractor of rural tourism. However, this does not necessarily imply that rural tourism is a miraculous catalyst of development in any rural context, with some authors calling for a more realistic view to evaluate the real potential of a rural area for successful and sustainable tourism development (Kastenholz, 2004; Ribeiro \& Marques, 2002; Saxena, Clark, Oliver, \& Ilbery, 2007; Sharpley, 2005). Appealing tourist attractions, basic services and facilities are needed, but may not be sufficient (Kastenholz, 2006). A good understanding of the market, its profile, behavior and motivations is also necessary to develop successful and competitive rural tourism products, which should help manage not only supply but also demand, yielding sustainable destination development (Kastenholz, 2004; Lane, 2009).

Several studies have already analyzed the rural tourist market in diverse countries (eg. Molera \& Albaladecho, 2007 in Spain; Frochot, 2005 in Scotland; Kastenholz, 2004 and Eusébio \& Kastenholz, 2011 in Portugal), however little is known about the Brazilian rural tourist market. It is in this context that the present study tries to contribute to an improved understanding of this market, more specifically agro-tourism, relying on the experience of all owners of agro-tourism accommodation units interviewed in the Southern half of Rio Grande do Sul, in a census approach, specifically in four different moments in time, from 1997 to 2011. This approach also permits analyzing the market's evolution. Results reveal common and distinct features of this market and may contribute to improved service, experience and destination marketing in rural areas in Southern Brazil.

\section{Agrotourism and rural tourism}

\subsection{Definitions}

Agro-tourism may be understood as a specific type of rural tourism or tourism taking place in rural areas. Calatrava and Avilés (1993) suggest that rural tourism should include rural culture as a core component, with personalized contact as relevant as integration into the rural environment and community life. Lane (1994) in his seminal article "What is rural tourism?" suggests that it should ideally be: located in rural areas; functionally rural (based on specific features and resources of the rural territory), rural (small) in scale and traditional in character, organically and slowly growing and controlled by local people. Some call for the presence of agriculture as a core element (e.g. Cavaco, 1995; Almeida \& Souza, 2006), while others stress the contrast to stressful, noisy and unhealthy urban life and the corresponding idealization of rural life (Figueiredo, 2008; Sims, 2009). However, a variety of motives have been identified when analysing the rural tourist market (Kastenholz, 2004; Frochot 2005; Molera \& Albaladecho, 2007), where the search of nature stands out (Eusébio \& Kastenholz, 2011; Figueiredo, 2008; Kastenholz Duane, \& Paul, 1999; Park \& Yoon, 2009; Frochot 2005), a personalized host-guest contact (Kastenholz \& Sparrer, 2009), an interest in exploring culture and history (Eusébio \& Kastenholz, 2011), with diverse motivational segments identifiable (Kastenholz et al., 1999; Frochot, 2005).

For those tourists seeking mostly to get to know and participate in the "rural way of life", agro-tourism should be the ideal form of rural tourism, but it actually only represents one segment or even "niche" amongst several "market niches", the rural tourism market is composed of (Clemenson \& Lane, 1997). It may, in fact, constitute a particularly relevant tourism format when considering its impact on rural development, since it may help maintain agriculture and associated activities pursued by farmers, through "pluri-activity" (Sharpley \& Vass, 2006; Williams \& Shaw, 1998).

Beni (2000, p. 9) defines agro-tourism as " $a$ movement of people to rural areas, in programmed or spontaneous routes, with or without overnight stay, for enjoying sceneries and observing, living and participating in farming activities". The author further explains that agro-tourism differs from rural tourism in so far as farming should represent the primary source of income, with tourism being complementary, while these farming activities represent simultaneously a distinct tourism attraction, permitting an experience of "authentic farm life" and even an active participation in it, if desired.

There is no official definition or classification of rural or agro-tourism in Brazil, but much of the existing supply is associated to a diversification of agriculture, taking place in working farms, with distinct dimensions and specializations, also shaped 
by the particularities of distinct Brazilian states (Almeida \& Souza, 2006).

Rural tourism is mainly based on urban demand, both in Brazil and in Europe (Cawley \& Gilmore, 2008; EMBRATUR, 1994; Figueiredo, 2008; Lane, 2009 ), very much motivated by the wish to escape form the stress of city life, return to nature and a relaxing, healthy life, leading to a potentially mutually beneficial encounter and exchange between the urban and the rural populations.

\subsection{Insights into the rural tourism market}

The rural tourist market has been growing in number and diversity in several, particularly European countries (European Commission, 1999; Lane, 2009; OCDE, 1994), being in some countries a predominantly domestic phenomenon (e.g. UK, Germany), in others also attracting the international tourist market (e.g. Italy, Austria, some regions of Spain and Portugal). Several studies carried out in Europe about this market reveal that rural tourists tend to belong to the mid-high class, possess higher levels of education, may be from all age ranges, with an increasingly experienced and demanding market looking for diversified experiences in both weekend short-break and long holiday contexts (European Commission, 1999; Lane, 2009; OCDE, 1994). Lane (2009) underlines the increasing relevance of the highly mobile, independent traveler, exploring diverse facets of rural territories. This traveler, searching new destinations and experiences, represents, according to recent data (Eurobarometer, 2010), a segment of about $28 \%$ of the European population.

Zimmermann (1996), Saxena et al. (2007) and Kastenholz, Carneiro, \& Marques (2012) stress that several elements integrate the overall tourism product in rural territories permitting diverse and complex experiences that respond to a wide set of motivations (Lane, 2009). Already mentioned important motivating factors may be summarized as follows, with motivations naturally overlapping:

- Search for proximity to nature (Eusébio \& Kastenholz, 2011; Figueiredo, 2008; Kastenholz et al., 1999; Park \& Yoon, 2009; Frochot 2005; Molera \& Albaladecho, 2007; Park \& Yoon, 2009; Rodrigues et al, 2010; Zimmermann, 1996) and activities in nature (rather sportive, recreational or observational), also just for its aesthetic pleasure (also the human-shaped landscapes are highly appreciated) and even spiritual fruition (Rodrigues \& Kastenholz, 2010).

- Looking for peace and quiet, as a main leitmotiv, seeking to escape the city, its stress, congestion, noise and pollution and slowing down, frequently associated with seeking health and wellness (Sidali \& Schulze, 2010; Lane 2009; Marques, 2006; Molera \& Albaladecho, 2007; Silva, 2009; Rodrigues et al 2010). This motive is close to the wish to just relax, get away from it all (Kastenholz et al, 2012b).

- On the other hand, there is a wish to be active, get involved, both in nature (e.g. more or less adventurous or physically demanding outdoors activities), and in a cultural/ educational sense (e.g. learning the preparation of a traditional dish, a handicraft, participating in harvests). Recreational opportunities (e.g. games, a swimming pool or tennis court) may be provided in the rural tourism context to address this wish of activity.

- Living a cultural experience, with traces from history also spread over rural territories (Eusébio \& Kastenholz, 2011; Ribeiro, Souto \& Santos, 2012), e.g. exploring monuments, castles and manor houses belonging to the rural aristocracy, but particularly through a broad interest in ethnography revealing specificities of rural living contexts (Kastenholz \& Sparrer, 2009; Pereiro \& Conde, 2005; Silva, 2009; Zimmermann 1996), for example through the contact with an artisan showing how to produce handicraft, through the participation in a local festivity with traditional folk music and dances or through the simple sharing of typical food;

- Interest in rural way of life, traditions, agriculture, local food, close social contacts (Cavaco, 1995; Sidali et al, 2013; Sims, 2009; Lane, 2009; Zimmermann 1996), sometimes associated to family origins or nostalgia of a "happy childhood", leading individuals with a migration background to return to their land of (family) origin (Rodrigues, Kastenholz \& Morais, 2012).

- Seeking a personalized host-guest contact, helping enter a distinct cultural context through "cultural brokerage" (Kastenholz \& Sparrer, 2009; Kastenholz, Eusébio, Carneiro, \& Figueiredo, 2013; Zimmermann 1996) and enhancing a unique type of experience and trustful, on-going relationships (Sidali et al, 2013; Loureiro \& Kastenholz, 2011). This personalized contact does not only occur in the tourism service, but also in a broader host community- visitor context and may be valued as a unique dimension of the overall rural tourist experience, by residents and visitors alike (Kastenholz, et al, 2012b).

- The wish to be together with friends and family in a distinct context, especially interesting for families with small children, for educational reasons (learn about rurality, traditions and nature) and due to the freedom of movement in natural spaces (Kastenholz \& Sparrer, 2009), 
revealing another important social dimension of the rural tourism experience (Molera \& Albaladecho, 2007).

- Living an experience rich in emotions and sensations, reaching from the aesthetic pleasures of beautiful landscapes, over the relaxing experience of sounds of nature and silence (absence of sounds!), the delighting, distinct flavors of local food and wine, the smells of food and nature and the tactile experiences regarding rough and varied material of nature and traditional craft (Agapito, et al., 2013; Kastenholz et al., 2012a; Loureiro \& Kastenholz, 2011; Marques, 2011; Pires, 2001).

- As a matter of fact, the food experience stands out as a sensorial, but also as a cultural one, representing food traditions of the visited place - in contrast to the frequently standardized urban food, people eat quickly for convenience - typically home-made dishes, with ingredients from the local agriculture, produced in traditional ways and consumed in particular, sometimes ritualistic contexts and being, by itself, a symbol of cultural identity of the territory/ community visited (Pereiro \& Conde, 2005; Sims 2009; Sidali et al, 2013).

Swarbrooke and Horner (2002) distinguish physical, cultural, emotional, personal, status and self-development motives, which apparently may all be satisfied in rural tourism contexts, as mirrored in the specific motivations identified above, which may, indeed, overlap or simultaneously condition one rural holiday experience. In this line of argument, Pires (2001, p. 57) suggests that a tourist staying at a rural property "[...] shows diffuse motivations, which are sometimes difficult to categorize, since motivations are many, all of them intertwined and nearly all of similar importance to the tourist." Indeed, different motives are frequently present in one tourist experience, while also a person's living context, for example shaped by one's family life cycle (particularly presence of young children, but also marital status), professional or health situation, determines motivational changes over time (Decrop, 2006). In any case, rural tourism motivations have been shown to be diverse, as is its tourist market, with distinct groups of people showing different (combinations of) motivations, undertaking distinct activities and consequently living distinct experiences when visiting rural areas (Clemenson \& Lane, 1997; Frochot, 2005; Kastenholz et al., 1999; Kastenholz et al, 2012a; Lane, 2009; Molera \& Albaladecho, 2007; Sidali $\&$ Schulze, 2010).
In Brazil, rural tourism is much associated to the diversification of agriculture, beginning with initiatives in 1986 in Lages/ Santa Catarina, while today numerous rural properties offer tourism activities (Ministério do Turismo, 2010). These are, however, neither legally classified, nor registered and no official statistics on the phenomenon exist, making its analysis a difficult task (Almeida \& Souza, 2006). The Brazilian Ministério do Turismo (2010, p. 16) recognizes that "the growth of rural tourism in Brazil has happened, mostly, in an 'empirical' way, with distinct features all over the country and even distinct designations".

According to a survey about $19.2 \%$ of the Brazilian population appreciates the countryside for holidays (MTur/Vox Populi, 2009, cited by Ministério do Turismo, 2010, p. 27). The segment is characterized as between 20 and 55 years old, including couples with children, with $\mathrm{mid} / \mathrm{high}$ level education, typically travelling by car in a range of up to $150 \mathrm{~km}$ from the urban residence for week-end or short-breaks. They make travel arrangements via internet, appreciate typical food and handicraft and are mainly attracted by the rural landscape and way of life (Ministério do Turismo, 2010).

\section{The study of agro-tourism in Rio Grande do Sul}

\subsection{Methodology}

The present study tries to assess agro-tourists' profiles and motivations, from the point of view of owners of rural tourism properties in the state of Rio Grande do Sul, approaching in a larger phd research project the rural tourism phenomenon looking at the evolution of rural tourism in this state, from the perspective of the owners of these establishments, their motivations to engage in the activity, their views regarding its impacts and also reasons for their eventual closing of the tourism business (...ref tese Eurico). The phenomenon was thus analyzed from the supply side perspective, concretely with in-depth interviews undertaken with the owners of all properties identified in 4 different moments in time, in a census approach, over 15 years: 9 rural tourism properties existing in 1997/1998; 43 properties in 2002/2003; 52 properties in 2005/2006; and 70 properties identified in 2011, all located in the Southern Half of Rio Grande do Sul. That is, the present study is singular in addressing all rural tourism units in a particular region (census) in a longitudinal approach over a 15 years period, resulting in a total of 174 responses in total (distributed over the four periods of time as 
Figure 1 - The location of properties approached in the census 2011.

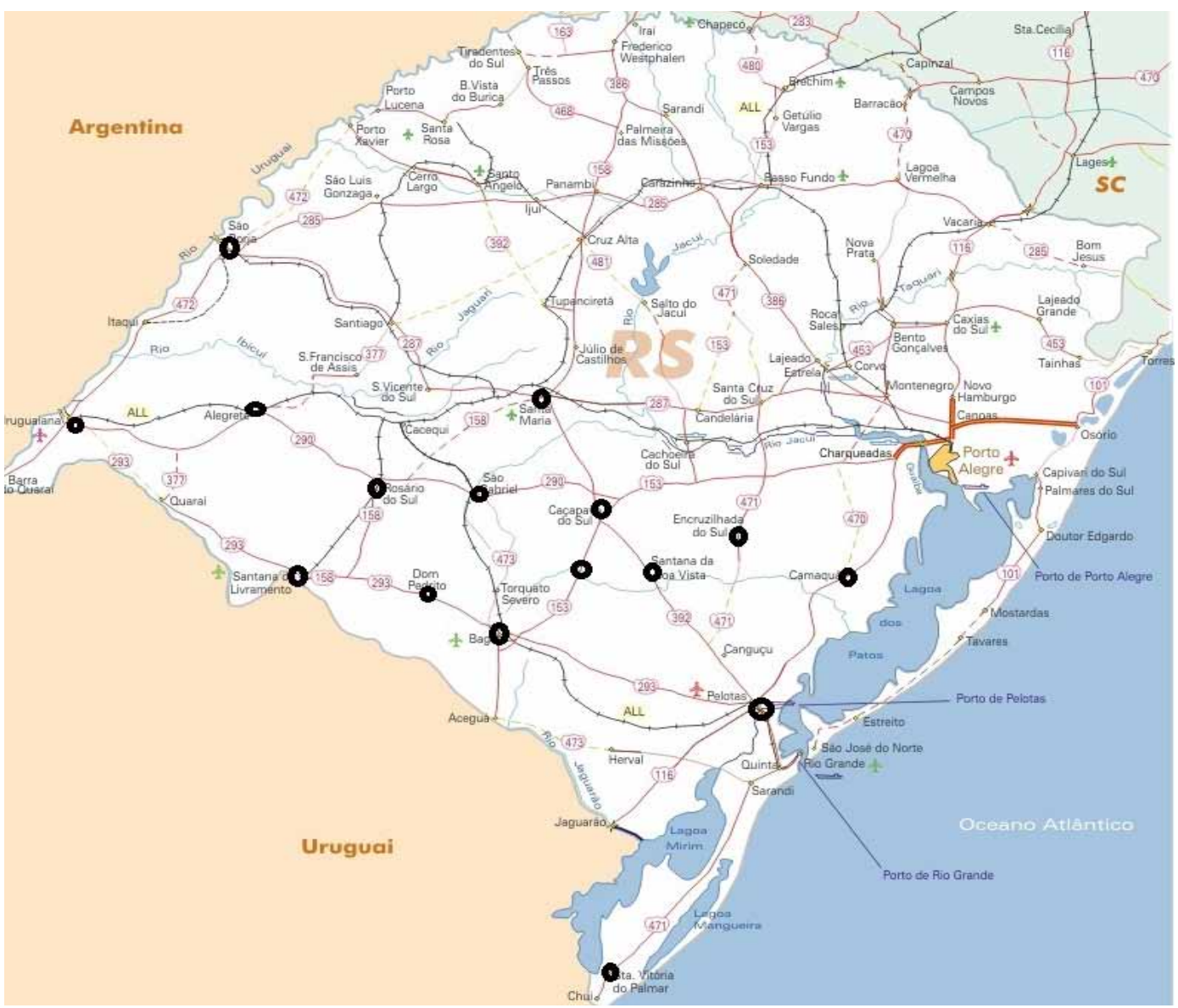

indicated above). For identifying these units the homepage of the Secretary of State of Rio Grande do Sul was used and all properties previously contacted. Some of the properties contacted had been permanently or temporarily closed down (namely $23 \%$ in 2002/ 2003; $27 \%$ in $2005 / 2006$ and $43 \%$ in 2011 , in respect to the previous period of study), while others had initiated the business, so that responses are not necessarily from the same owners over time. However, we consider that they should reflect a pattern of responses revealing indices of an evolution of the market, its features, motivations and dynamics.

The motivation of most farmers investing in agri-tourism was the search of additional income for economically stimulating the property and sometimes for being able to keep it and maintain the family together on the farm, with also an interest in socializing of farmers with visitors observable, an awareness of the scenic beauty and cultural values of the properties, while particularly in recent years increased tourist demand is referred to as a motivation to open an agri-tourism business. These businesses are typically of small scale (although the percentage of those offering between 1 and 5 rooms has decreased from $62.5 \%$ in $1997 / 98$ to $37.8 \%$ in 2011 , with the second most relevant category being between 6 and 10 beds and a very small number offering more than this). However, it must be noted that also a relevant number of agri-tourism units have closed down in this period, mainly due to unsatisfactory results (too few tourists, too little income given the investment) or due to difficulties in matching tourism with other activities, agriculture and family life and in having sufficiently skilled human resources available.

The main survey was administered directly by the second author, in an interview format. This very time consuming procedure (the properties 
where located in very disperse and not easy to reach places in a territory of about $154.000 \mathrm{~km} 2$, see figure 1) resulted in particular attention given to each case (typically the researcher stayed for some hours and sometimes he had to stay overnight) and yielded a good understanding of each case's context, permitted field observations (regarding the surroundings and specificities of the unit), supported by photographic registers. It also led to a high response rate (all those contacted responded, however not necessarily to all questions), permitted explanations of some questions and the recording of also open-ended questions, which frequently are left unanswered in an indirect mailing approach.

The questions were specifically elaborated for this research project yielding an understanding of the owner's profile, motivations to invest in tourism, the rural tourism product presented, management of the tourism activities, but also the profile and motivations of tourists visiting the units, from the owners' perspective, given the close contact between hosts and guests. Both closed-ended and open-ended questions were used, the former permitting direct statistical treatment, the latter requiring transcriptions, content analysis, categorization of responses to also permit some statistical analysis.

The choice of the property owner as respondent and not of the tourist is due to the main interest of the phd research project being an understanding of the way tourism is implemented in a working farm, thereby addressing the farm owners. On the other hand, however interesting, it should be practically impossible to obtain both a census of owners and a representative sample of tourists visiting each unit, given the direct administration approach (units were geographically dispersed and tourists not always present at the time of the researcher visiting the unit). Still, in the present article this indirect assessment of tourist motivations must be recognized as a limitation, however attenuated through the fact that most of them had close contact and frequent talks with their (many of them loyal) guests, making them knowledgeable about their guests' profile.

Considering that Porto Alegre, the capital of Rio Grande do Sul, is the State's main population center, the distance of each unit from this city was calculated, this being a relevant determining factor for visitation. Most rural tourism properties are located at a distance of between 301 and $500 \mathrm{~km}$ of the capital (61.4\%), while $37.1 \%$ are located between $100 \mathrm{~km}$ até $300 \mathrm{~km}$ from Porto Alegre. According to Zimmermann (1996) and Ministério do Turismo (2010), rural tourism is mostly demanded by people coming from a distance of up to $150 \mathrm{~km}$, suggesting a most relevant proximity market, while the present study also reveals a market of longer distances.

\subsection{Survey results}

\subsubsection{The clients' profile}

The large majority of clients of agro-tourism units are reported to be in the age classes between 29 and 64 years, with the age distribution apparently more equilibrated in the last year of data collection (2011), when apart from this largely dominating group (mentioned by $90 \%$ of owners), increasingly also children, adolescents, young adults (up to 28 years) and senior tourists (above 65 years) were mentioned, when compared with previous periods of analysis. Owners identified as main professional occupations liberal, scientific professions, medical doctors and lawyers, revealing a predominantly high socio-economic status of visitors. The impression some owners retain from their clients is expressed in the following discourses: "they come with luxury cars, appreciate the [transitory] change from city to the farm life and say they will come back". They tend to identify most clients as "people with money".

Table 1 shows that rural tourism properties in Rio Grande do Sul attract predominantly families with children, however with a slightly diminishing trend since 2002. Properties seem particularly attractive for families, offering packages with all meals included, permitting a contact with animals that city children only know from books, space for them to run and play freely, amongst other features. A second outstanding tourist group are friends, this being an apparently increasingly important client segment since 2002, which is also true for trips with the "entire family".

Visitors come mainly from urban areas within the region of the establishment (44,4\%) or from larger distances within the state of Rio Grande do Sul (66.7\%), with some flows observable from outside the federal State $(38,9 \%)$ and even from outside Brazil (19,4\% mainly Uruguay and Argentina), with the same amount being observed for the closest, the municipality level. One owner states that "we have already welcomed visitors from Australia, Germany, EUA and Japan." However, the here studied agro-tourism reality seems to be mainly a domestic phenomenon.

These numbers (with multiple responses) refer to 2011 and show a relative increase since 2002 in the categories "regional" and "from another federal State". It is interesting to note that the very close market does, in fact, not adhere as much to the existing rural tourism offering, while the attraction 
Table 1. Clients of rural tourism properties.

\begin{tabular}{l|c|c|c|c|c|c}
\hline \multirow{2}{*}{} & \multicolumn{2}{|c|}{$2002-2003$} & \multicolumn{2}{c|}{$2005-2006$} & \multicolumn{2}{c}{2011} \\
\cline { 2 - 7 } & Freq. & Perc. & Freq. & Perc. & Freq. & Perc. \\
\hline Spouse and children & 26 & 89,7 & 29 & 85,3 & 25 & 78,1 \\
Spouse/partner & 8 & 27,6 & 9 & 26,4 & 7 & 21,9 \\
Friends & 3 & 10,3 & 4 & 11,8 & 7 & 21,9 \\
Single parent with children & 2 & 6,9 & - & - & - & - \\
Grandparents with grandchildren & - & - & 2 & 5,9 & 1 & 3,1 \\
Entire family & - & - & 2 & 5,9 & 4 & 12,5 \\
Honeymoon couples & 1 & 3,4 & - & - & - & - \\
No respondents & 29 & - & 34 & - & 32 & -
\end{tabular}

* multiple response

Source: survey of agro-tourism owners in Southern Rio Grande do Sul

Note: several responses possible

over longer distances seems to be quite common. As one agro-tourism owner explains, "mostly people do not complain about the distance from the (state) capital (where most of his clients come from), they come and feel at home here". Similarly, another owner states: "even coming from far away, they like to come to this place." However, one referred to "some say they would come more often, if it was closer (to their place of residence)".

Table 2 reveals that the vast majority of clients stay between one and two nights $(67,6 \%$, in 2011), with an apparently increasing tendency towards this short break stay. The second most relevant visitation type is that of just one day $(32,4 \%)$, the cheapest option, while only $10.8 \%$ (in 2011) are identified as clients staying between 3 and 4 nights. These is related, for once, to a weekend short-break pattern of rural tourism in Rio Grande do Sul, where most do apparently not consider the rural tourism experience interesting enough for a longer stay. Some also only pass by, visiting farms as a tourist attraction for the same day, as mentioned by one owner: "Sometimes they come with a group of elderly, in an (organized) excursion, they spend the day here and leave again." The units are also sometimes used, for convenience, on the way to another destination.

Additionally, several owners identify a particular seasonality of tourist flows: "In summer, they go to the beach, we have more demand in winter" or

Table 2. Length of stay of clients in rural properties

\begin{tabular}{l|c|c|c|c|c|c}
\hline \multirow{2}{*}{ Length of Stay } & \multicolumn{2}{|c|}{$2002-2003$} & \multicolumn{2}{c|}{$2005-2006$} & \multicolumn{2}{c}{2011} \\
\cline { 2 - 7 } & Freq. & Perc. & Freq. & Perc. & Freq. & Perc. \\
\hline One day visit & 8 & 25 & 12 & 31,6 & 12 & 32,4 \\
1 to 2 nights & 19 & 59,4 & 19 & 50 & 25 & 67,6 \\
3 to 4 nights & 6 & 18,8 & 11 & 28,9 & 4 & 10,8 \\
\hline Total number of responses & 32 & - & 38 & - & 37 & - \\
\hline
\end{tabular}

Source: survey of agro-tourism owners in Southern Rio Grande do Sul

Note: several responses possible 
Table 3. Motives for visiting rural tourism properties in Southern Rio Grande do Sul

\begin{tabular}{|c|c|c|c|c|c|c|}
\hline \multirow{2}{*}{ Tourist motivations } & \multicolumn{2}{|c|}{$2002-2003$} & \multicolumn{2}{|c|}{$2005-2006$} & \multicolumn{2}{|c|}{2011} \\
\hline & Freq. & Perc. & Freq. & Perc. & Freq. & Perc. \\
\hline \multicolumn{7}{|l|}{ Nature } \\
\hline Proximity to nature & 12 & 37,5 & 5 & 14,3 & 2 & 5,6 \\
\hline Proximity to nature/freedom for children & 3 & 9,4 & & & & \\
\hline \multicolumn{7}{|l|}{ Culture } \\
\hline Learning about the animals & 7 & 21,9 & & & & \\
\hline Learning about the farms & 2 & 6,3 & 2 & 5,7 & & \\
\hline Learning about local/regional culture & & & 4 & 11,4 & 16 & 44,4 \\
\hline Gastronomy & 2 & 6,3 & 1 & 2,9 & 1 & 2,8 \\
\hline History & 1 & 3,1 & 3 & 8,6 & & \\
\hline \multicolumn{7}{|l|}{ Social } \\
\hline Be together with children & 2 & 6,3 & & & & \\
\hline Socialize with owners & 2 & 6,3 & & & & \\
\hline \multicolumn{7}{|l|}{ Hospitality/Service context } \\
\hline Private environment & 1 & 3,1 & 1 & 2,9 & & \\
\hline Personalized service & 2 & 6,2 & 1 & 2,9 & & \\
\hline \multicolumn{7}{|l|}{ Recreational } \\
\hline Fishing & 1 & 3,1 & & & & \\
\hline Differentiated program & 2 & 6,3 & 2 & 5,7 & & \\
\hline Horse riding & 3 & 9,4 & 3 & 8,6 & & \\
\hline Entertainment & 1 & 3,1 & 1 & 2,9 & 1 & 2,8 \\
\hline \multicolumn{7}{|l|}{ Relaxing/escape from city stress } \\
\hline Peace and quiet & 15 & 46,9 & 4 & 11,4 & 1 & 2,8 \\
\hline Rest & 6 & 18,8 & 2 & 5,7 & 3 & 8,3 \\
\hline Quality of Life & 1 & 3,1 & & & & \\
\hline Physical wellness/Health & 3 & 9,4 & 7 & 20 & 8 & 22,2 \\
\hline \multicolumn{7}{|l|}{ Self development } \\
\hline Self development & & & 1 & 2,9 & 2 & 5,6 \\
\hline Freedom & 1 & 3,1 & 1 & 2,9 & & \\
\hline Emotional & & & 4 & 11,4 & 10 & 27,8 \\
\hline \multicolumn{7}{|l|}{ Nostalgia } \\
\hline My roots & 7 & 21,9 & & & & \\
\hline \multicolumn{7}{|l|}{ Convenience } \\
\hline Proximity to urban center & 1 & 3,1 & 1 & 2,9 & & \\
\hline Safe roads & 2 & 6,3 & & & & \\
\hline Ease of access & 1 & 3,1 & & & 1 & 2,8 \\
\hline Safety & 5 & 15,6 & 1 & 2,9 & & \\
\hline \multicolumn{7}{|l|}{ Other } \\
\hline Particular motives & & & 3 & 8,6 & 5 & 13,9 \\
\hline Like the place & & & 3 & 8,6 & & \\
\hline
\end{tabular}

Source: survey of agro-tourism owners in Southern Rio Grande do Sul

Note: several responses possible 
"when there is a public holiday, particularly close to the weekend, I am out-booked, I could host more people, if I had so many rooms, but there are also times nobody comes."

On the other hand, many clients are remarkably loyal, coming back to the visited rural tourism property $(86,5 \%$, in 2011$)$, typically once or twice a year, some even three to four times, but others never return. This behavior (that has not changed much since 2002) reflects the preference for several short breaks along the year in the countryside over a longer holiday stay. The following statement of one owner exemplifies this pattern: "they come for little time, but they like this rural environment, and like to come back". One owner of a farm providing horse riding says: "the kids (in the tourist group) always want the same horse", revealing a particular type of loyalty, interestingly including loyalty to certain farm animals, or a certain type of place attachment, which is in fact close to place dependence, referring to a set of social and physical features that meet the individual's specific needs and permit desired activities and represent what is unique in the place, differentiating it from any other alternative one (Bricker \& Kerstetter, 2000; Silva et al, 2013).

\subsection{Tourists' motivations}

Owners of rural establishments were asked about their clients' main specific motivations, leading to a large number and variety of responses which are presented and categorized into the following broad categories, as derived from the literature review (see section 2.2.). The responses to the open-end questions are naturally varied and make a comparison over time difficult (see Table 3).

Relaxation in a quiet and peaceful environment as a general motivation of most rural tourists, identified in many studies on the respective market, is also important here, but has apparently lost its relevance, although it may just be named differently in the study undertaken in 2011, where people refer to a more holistic wellness and health motive, which should indeed be partly related to relaxation, but can also assume more active pursuits. So it is worth of notice that just relaxation may indeed not be the outstanding motivation any more, being increasingly associated to a broader view of a healthy, balance providing and emotionally colored experience, which is simultaneously culturally enriching.

So, even if some "may come just to relax and enjoy the peace and quiet", "they want to get away from the city", "eventually reading books and not doing anything else", others refer to visitors "liking to participate in rural activities", "providing their children a contact with farm and domestic animals they do not have in the city", enjoying "walking on the trails in the property", especially through forested nature areas, appreciating "swimming in a pool in the middle of the countryside", and many being interested in "horse riding", being also a frequently mentioned motive for coming back (and riding the same horse).

Agro-tourism units close to the border to Uruguay also refer to an interest of clients in "shopping in Uruguay". This emphasis on diverse "particular motives" points at new, eventually more diversified patterns of tourist motivation, making a classification and a homogenous description of "the rural tourist" highly questionable.

When asked about the reasons about visitors' loyalty to their property, owners of rural tourism units understand that their clients tend to come back, mostly due to the fine hospitality, the personalized way they are welcomed at the property, generally in a family ambiance: "They like the way we treat them here, they feel truly welcome", as one owner puts it. But owners also understand the importance of the specific features of their properties and surrounding environment, making people "attached to the place", by providing the ideal context for seeking close contact to nature in the rural tourism property and the associated health benefits ("pure air") tourists seek, while others refer to the attractions/ activities available at the properties, with gastronomy and horseback riding particularly standing out. Also a general escape from stress is a frequently mentioned underlying motive again in responses to this question, confirming studies in other contexts (Sidali \& Schulz, 2010; Kastenholz et al., 2012; Lane, 2009; Molera \& Albaladecho, 2007; Silva, 2009). Some also refer to the particular location, the liking of the region the property is integrated in, as a reason to come back, while others refer even to animals, some clients (or their kids) get affected to, as mentioned before, all creating loyalty, place attachment and sometimes even place dependence (Silva et al, 2013).

When asked about activities sought by clients, owners refer to horse riding as the most outstanding activity (however slightly declining since 2002), and to swimming in swimming pools (slightly increasing in relevance). Other most sought activity opportunities are hiking on ecological trails (showing an increasing trend) and observing/ participating in agricultural activities (e.g. milking cows, observing animal vaccination, harvesting, etc., another increasing trend). Also rustic playgrounds, football and volleyball grounds and river beaches/ waterfalls are highly appreciated. Owners are able to number a large variety of different specific activities revealing 
a vast range of recreational, cultural/ educational and sportive activities/ facilities, confirming the idea of rural tourists being increasingly active and motivated by distinct interests, eventually also due to the fact that they often come with family and friends, i.e. in groups composed of individuals with distinct interests. Frequently, families visiting rural properties are quite heterogeneous, with parents sometimes nostalgically returning to their rural origins, while their children only know city life. The wish to show their children life in a rural area, presenting them with their original family background is oftentimes an important motif for the visit, but owners have understood that for the children, so used to urban life, they need to present other kinds of attractions to make them also enjoy their stay in the rural property.

The variety of opportunities presented reveals the owners' capacity of developing new products/ attractions, based on existing natural and cultural resources, as well as on their own investment in facilities they understand to be attractive to tourists, i.e. revealing some level of entrepreneurship, capacity to adapt to market needs, which may be one important reason for the high levels of loyalty obtained from their clients. As a matter of fact, the recreational activities suggested are not exclusive neither necessarily related to agriculture or the countryside, like swimming pools, sports facilities or even saunas, which are mostly signs of an adaptation to the urban visitors' tastes.

\section{Conclusions}

In the Southern Half of Rio Grande do Sul there is an intense debate about the role and future of agro- and rural tourism, which should be based on a sound knowledge of the phenomenon. The main goal of the here presented study is to shed light on rural tourism in this region, considering its evolution overtime and looking here, particularly, at the property owners' perception of this market, in terms of profile, motivation and travel behavior. Many owners seem to be successful in attracting and creating a loyal client base by matching the needs and desires of a generally well educated, professionally active, urban couples and families, coming for short breaks of typically 1 or 2 nights, frequently several times a year. Hospitality and the special, familiar welcoming of clients seems to be relevant for coming back, confirming Avena's (2001) emphasis on the warm, personalized service context as a particularly sought dimension of rural tourism, probably in contrast to the anonymous city life and standardized hotel comfort provided in other tourism contexts (Kastenholz \& Sparrer,
2009). This, plus perceived unique features of the property, where even the attachment to animals plays a role, but also way the property provides the opportunity to relax from stressful city life in a natural, healthy environment, on the one hand, and to engage in certain activities (including agricultural) and experiences (including learning experiences), create loyalty to the unit, but also place attachment and even place dependence (Bricker \& Kerstetter, 2000; Silva et al, 2013).

The here identified relevance of a health/ wellness motive associated to nature corroborates results of a study undertaken by Hanai in Minas Gerais about the rural tourist market: " The majority of tourists visits these nature areas [...] motivated by the contact with preserved nature, seeking tranquility, peace and quiet, relaxation and an escape from the daily routine and stress" (2009, p.110). It further confirms an apparently global trend of urban populations seeking to escape the city transitorily, as found in other contexts (Kastenholz et al., 2012; Lane, 2009; Molera \& Albaladecho, 2007; Sidali \& Schulze, 2010; Silva, 2009). However, one important finding of the present study is the fact that most owners do not refer as frequently as before the single motivation "relaxation", a typical escape motive, but instead suggest increasingly a more holistic health/ wellness motive, which would naturally include relaxation from stress, while also implying more active pursuits, as also observable in the trend towards more activities mentioned and towards the increasingly emotion-rich experience sought.

This may confirm a general trend within tourism demand, the post-modern tourist being frequently suggested to be more open to new and different experiences, interested in getting involved and valuing the emotional outcome of the holidays, which may, indeed apply perfectly to rural tourism experiences (Kastenholz et al, 2012; Walmsley, 2003).

Additionally, specific attractions/ activities available at the properties, particularly related to gastronomy and horseback riding are other important motives for rural tourism in Rio Grande do Sul, but also opportunities to get to know and get involved in agricultural and traditional activities, and sometimes learning about local/ regional history and culture, confirming results of Ribeiro et al's (2012) study. There seems to be a need to present a balanced offer, based on highly valued endogenous natural and cultural resources, but also including more urban-like recreational facilities, permitting diverse opportunities for multi-motivated tourists seeking emotionally involving experiences, in a safe, relaxing, healthy and welcoming environment. This multi-motivational rural tourism demand should also 
be due to the fact that many hosts come in groups with diverse family members, sometimes with friends, individuals with distinct interests and preferences, a varied offer would best adapt to.

Owners interviewed in this survey, particularly those who maintained their unit open and eventually also increased their (still small-scale) offer of accommodation, show this capacity of providing satisfactory rural tourist experiences making clients come back several times a year. However, not all have succeeded and even decided to close down their business, due to lack of profitability and difficulty of adaptation to this type of market and activity (quite different from agriculture), while those who keep the business, apparently have not succeeded yet in changing the pattern of the weekend short-break to a longer holiday stay, eventually requiring additional management and marketing efforts, since longer stays should help contribute to more sustainable rural tourism development, as well as to more involving and significantly recalled experiences and richer host-guest relationships, for both visitors and visited alike (Kastenholz et al, 2013).

It is noteworthy that some of the motives and trends reveal a real opportunity for farm owners in Brazil diversifying into tourism and able to provide not only a genuine welcoming atmosphere, but also diverse experiences based on endogenous resources, local food and its traditional preparation, on the local nature environment, which may be additionally prepared for leisure and sports activities (especially hiking and swimming), the maintenance of animals, particularly horses (for horse riding), to increase their income through tourism services, while simultaneously enhancing local farming produce, especially food production (not only for consumption during the stay, but also for selling directly to the hosts as souvenirs). This type of tourism, even if to a certain degree adapted to the taste of the urban guests, is also likely to enhance the maintenance of local traditions, which are valued by visitors, as unique and different from the standardized urban way of life. All this, plus the opportunity of enjoying increased social contacts and thereby overcoming the relative isolation of living in rural areas, as highlighted by Kastenholz et al (2013) for village populations in Portugal, the local residents' quality of life may indeed be enhanced, possibly leading farmers and their families to stay in areas, which are sometimes perceived as less attractive for living. Consequently, all this implies a large potential of sustainable rural tourism development in the here studied Brazilian farms, contributing to farm families' economic survival, to continued agricultural activities, which also benefit from tourism while simultaneously benefiting it, to landscape and heritage preservation and to their setting into value, also enhancing local culture and sense of identity (Bramwell \& Lane 1993; Kastenholz, 2004; Saxena et al, 2007).

In any case, the here presented results are perceptions of agro-tourism promoters and should be complemented by a survey of tourists visiting these units, however difficult the implementation of such a study. With a sufficiently large and representative sample, also a cluster analysis could be undertaken, helping identify segments seeking distinct benefits in the Brazilian rural areas and correspondingly improve the units' and destination's capacity of developing well-adapted products to carefully selected markets (Kastenholz, 2004; Frochot, 2005).

\section{Bibliography}

Agapito, D., Almeida, H., Mendes, J. and Valle, P. 2013 "A contribution to marketing sustainable sensory-themed tourist experiences in rural destinations". In Proceedings of the International Conference on Rural Tourism: Re-inventing rural tourism and the rural tourism experience - Conserving, innovating and co-creating for sustainability, 4th - 7th September 2013. Aveiro: University of Aveiro.

Almeida, J. A. and Souza, M. (org.)

2006 Turismo Rural: patrimônio, cultura e legislação. Santa Maria, RS: FACOS-UFSM.

Avena, B. M.

2001 "Acolhimento de Qualidade: fator diferenciador para o incremento do turismo na sociedade pós-industrial”. Revista Turismo em Análise, 12(1: 20-29.

Beni, M. C.

2000 "Turismo - visão e ação (Glossário). Turismo - Visão e Ação". Revista Científica do Mestrado em Turismo e Hotelaria, 4(2): 9, 25-28.

Bramwell, B. and Lane, B.

1993 "Sustainable Tourism: an evolving global approach". Journal of Sustainable Tourism, 1(1): 1-12.

Bricker, K. and Kerstetter, D.

2000 "Level of Specialization and Place Attachment: An Exploratory Study of Whitewater Recreacionists". Leisure Sciences, 22: 233-257.

Calatrava, J. and Avilés, P. R.

1993 "O turismo, uma oportunidade para as zonas rurais desfavorecidas?”. In Cadernos LEADER. Comercializar um turismo rural de qualidade (pp. 9-18). Bruxelles: Célula de Animação LEADER (AEIDL). 
Cavaco, C.

1995 "Rural Tourism: The creation of new tourist spaces". In Montanari, A. and Williams, A. M. (Eds.). European Tourism: Regions, Spaces and Restructuring (pp. 127 - 149). Chichester: European Science Foundation, John Wiley \& Sons.

Cawley, M. and Gillmor, D. A.

2008 "Integrated rural tourism: Concepts and Practice". Annals of Tourism Research, 35(2): 316-337.

Clemenson, H. A. and Lane, B.

1997. "Niche markets, niche marketing and rural employment". In Bollman, R. D. and Bryden, J. M. (Eds.). Rural Employment: An International Perspective (pp. 410-426). Wallingford: CAB International.

Decrop, A.

2006 Vacation Decision Making. Oxfordshire: CABI Publishing.

Embratur

1994 Manual Operacional do Turismo Rural. Brasília: Instituto Brasileiro de Turismo.

Eurobarometer - European Commission

2010 "Survey on the attitudes of Europeans towards tourism, Analytical report: Flash". Eurobarometer Series n ${ }^{\circ} .291$.

European Commission

1999 Towards quality rural tourism - integrated quality management. Luxembourg: Office for Official Publication of the European Communities.

Eusébio, C. and Kastenholz, E.

2011 "Quem procura o Turismo no Espaço Rural? Especificidades do mercado da Região Centro de Portugal". In Figueiredo, E., Kastenholz, E., Eusébio, M. C., Gomes, M. C., Carneiro, M. J., Batista, P. and Valente, S. (Coords.). O Rural Plural - Olhar o Presente, Imaginar o Futuro (pp. 215-230). Castro Verde: 100Luz Editora.

Figueiredo, E.

2008. "Imagine there's no rural - the transformation of rural spaces into places of nature conservation in Portugal". European Urban and Regional Studies, 15(2): 159-171.

Frochot, I.

2005 "A benefit segmentation of tourists in rural areas: a Scottish perspective". Tourism Management, 26(3): 335-346.

Hanai, F. Y.

2009 Sistema de indicadores de sustentabilidade: uma aplicação ao contexto do desenvolvimento do turismo na região de Bueno Brandão, estado de Minas Gerais, Brasil. Tese Doutorado (Ciências da Engenharia Ambiental). São Carlos/SP.

Kastenholz, E.

2004 "Management of Demand as a Tool in Sustainable Tourist Destination Development". Journal of Sustainable Tourism, 12(5): 388-408.
Kastenholz, E.

2006 "O marketing de destinos turísticos - o seu significado e potencial, ilustrado para um destino rural". RDT/ Journal of Tourism and Development, 6: 31-44.

Kastenholz, E. and Sparrer, M.

2009 "Rural Dimensions of the Commercial Home".

In Lynch, P., MacIntosh, A. and Tucker, H.

(Eds.). Commercial Homes in Tourism: An international perspective (pp. 138-149). London: Routledge.

Kastenholz, E., Carneiro, M. J., and Marques, C. 2012 "Marketing the rural tourism experience". In Tsiotsou, R. H. and Goldsmith, R. E. (Eds.). Strategic Marketing in Tourism Services (pp. 247-264). Bingley: Emerald.

Kastenholz, E., Duane, D. and Paul, G.

1999 "Segmenting Tourism in Rural Areas: The case of North and Central Portugal". Journal of Travel Research, 37(4): 353-363.

Kastenholz, E., Eusébio, C., Carneiro, M. J. and Figueiredo, E.

2013 "Host-Guest relationships in rural tourism - evidence from two Portuguese villages". Anatolia: An International Journal of Tourism and Hospitality Research.

Kastenholz, E., Carneiro, M. J., Marques, C. P. and Lima, J.

2012 "Understanding and managing the rural tourism experience - the case of a historical village in Portugal". Tourism Management Perspectives, 4: 207-214.

Lane, B.

1994 "What is rural tourism?". Journal of Sustainable Tourism, 2(1): 7-21.

Lane, B.

2009 "Rural Tourism: An Overview". In Jamal, T. and Robinson, M. (Eds.). The SAGE Handbook of Tourism Studies (pp. 354-370). London: Sage Publications.

Loureiro, S. M. C. and Kastenholz, E.

2011 "Corporate reputation, satisfaction, delight, and loyalty towards rural lodging units in Portugal". International Journal of Hospitality Management, 30(3): 575-583.

Marques, Carlos P.

2011 "Mapping affective image of destinations". Encontros Científicos - Tourism \& Management Studies, 2(7): 1040-1043.

Ministério do Turismo

2010 Turismo Rural: Orientações Básicas. $2^{\mathrm{a}}$ Ed. Brasília: Ministério do Turismo.

Molera, L. and Albaladejo, I. P.

2007 "Profiling segments of tourists in rural areas of South-Eastern Spain”. Tourism Management, 28(3): 757-767. 


\section{OCDE}

1994 Tourism Strategies and Rural Development. Paris: OCDE/GD. (94) 49.

Park, D. B. and Yoon, Y. S.

2009. Segmentation by motivation in rural tourism: A Korean case study. Tourism Management, 30(1): 99-108.

Pereiro, X. and Conde, S. P.

2005 "Turismo e oferta gastronómica na comarca de Ulloa (Galiza): Análise de uma experiência de desenvolvimento local. Pasos". Revista de Turismo and Patrimonio Cultura, 3(1): 109-123. Pires, J. M.

2001 "O turismo rural e a preservação de valores sócio-culturais". In Oliveira, Cássio G. S. (Ed.). O Sucesso como possível fator de descaracterização de empreendimentos de turismo rural. Anais do $3^{\circ}$ Congresso Brasileiro de Turismo Rural. Piracicaba: FEALQ.

Ribeiro, M. and Marques, C.

2002 "Rural tourism and the development of less favoured areas between rhetoric and practice". International Journal of Tourism Research, 4(3): 211-220.

Ribeiro, M., Souto, C. B. and Santos, E. O.

2012 "A Valorização da Memória e do Patrimônio Cultural Como Atrativos Turísticos em Propriedades Rurais do Rio Grande do Sul", Revista Rosa dos Ventos, 4(II): 151-163.

Rodrigues, Á., Kastenholz, E., and Morais, D.

2012 "Travel constraints and nostalgia as determinants of cross-Atlantic legacy tourism". In Pechlaner, H., Lee, T. J. and Dal Bò, G. (Eds.). New Minorities and Tourism - Proceedings of the International Scientific Workshop on New minorities and Tourism (pp. 75-92). Bolzano: European Academy of Bolzano/Bozen.

Rodrigues, A. and Kastenholz, E.

2010 "Hiking as a relevant wellness activity results of an exploratory study of hiking tourists in Portugal applied to a rural tourism project". Journal of Vacation Marketing, 16(4): 331-343.

Rogrigues, A. and Kastenholz, E.

2010 "Sentir a Natureza - passeios pedestres como elementos centrais de uma experiência turística”. Revista de Turismo \& Desenvolvimento, 13/14(2): 719-728.

Saxena, G., Clark, G., Oliver, T. and Ilbery, B.

2007 "Conceptualizing Integrated Rural Tourism. Tourism Geographies: An International”. Journal of Tourism Space, Place and Environment, 9(4): 347 - 370.

Sharpley, R.

2005 "Managing the countryside for tourism: a governance perspective". In Pender, L. and Sharpley, R. (Eds.). The Management of Tourism (pp. 175-186). London: Sage Publications.
Sharpley, R. and Roberts, L.

2004 "Rural tourism - 10 years on". International Journal of Tourism Research, 6(3): 119-124.

Sharpley, R. and Vass, A.

2006 "Tourism, farming and diversification: An attitudinal study". Tourism Management, 27(5): 1040-1052.

Sidali, K. L. and Schulze, B.

2010 "Current and future trends in consumers' preference for farm tourism in Germany". Leisure/Loisir, 34(2): 207-222.

Sidali, K., Kastenholz, E. and Bianchi, R.

2013 "Food tourism, niche markets and products in rural tourism: combining the intimacy model and the experience economy as a rural development strategy". Journal of Sustainable Tourism, DO I:10.1080/09669582.2013.836210

Silva, C., Kastenholz E. and Abrantes, J. L.

2013, "Place attachment, destination image and impacts of tourism in mountain destinations". Anatolia: An International Journal of Tourism and Hospitality Research, DOI:10.1080/13032 917.2012.762312

Silva, L.

2009 Casas no campo. Etnografia do Turismo Rural em Portugal. Lisboa: Imprensa de Ciências Sociais.

Sims, R.

2009 "Food, place and authenticity: local food and the sustainable tourism experience". Journal of Sustainable Tourism, 17(3): 321-336.

Swarbrooke, J. and Horner, S.

2002 O comportamento do consumidor no turismo. São Paulo: Aleph.

Walmsley, D. J.

2003 "Rural tourism: a case of lifestyle-led opportunities". Australian Geographer, 34: 61-72.

Williams, A. and Shaw, G. (Eds.).

1998 Tourism and economic development: European experiences. $3^{\text {rd }}$ ed. Chichester: Wiley.

Zimmermann, A.

1996 Turismo Rural: um modelo brasileiro. Florianópolis: Ed. do Autor.

Recibido:

$04 / 11 / 2013$

Reenviado:

$16 / 12 / 2013$

Aceptado:

$11 / 02 / 2014$

Sometido a evaluación por pares anónimos 